\title{
Healthcare workers' attitudes toward hand hygiene practices: Results of a multicentre qualitative study in Quebec
}

\author{
Sara Atif ; ${ }^{1}$ Armelle Lorcy; ${ }^{2}$ Eve Dubé ${ }^{2}$ \\ ${ }^{1}$ Université Laval \\ ${ }^{2}$ Centre de recherche du CHU de Québec-Université Laval
}

\section{Corresponding author:}

Eve Dubé

2400 D'Estimauville

Québec, QC G1E 7G9 Canada

Tel.: 418-666-7000 x 295

eve.dube@inspq.qc.ca

\begin{abstract}
Background: Hand hygiene $(\mathrm{HH})$ is one of the most effective practices to reduce healthcare-associated infection (HAI) transmission, though compliance remains inadequate among hospital personnel. The aim of this study was to explore perceived barriers and enablers of $\mathrm{HH}_{\mathrm{H}}$ compliance in hospital care and healthcare workers' (HCW) HAl risk and severity perceptions.
\end{abstract}

Methods: Qualitative study using semi-structured interviews and observations. Interview recordings were transcribed verbatim and supplemented with transcribed observations and field notes. Data was aggregated and coded thematically using a qualitative data analysis software.

Results: 65 interviews and 18 observations with HCWs were conducted in nine hospital centres in Quebec, Canada. Data analysis revealed several factors that may influence HCWs' compliance with $\mathrm{HH}$ recommendations. These included clinical environment factors (e.g., lack of sinks), organizational factors (e.g., inadequate staffing, demanding workloads), and communication factors (e.g., dissemination of infection prevention and control [IPAC] information, feedback, and interpersonal professional relationships). At the individual level, knowledge of IPAC and $\mathrm{HAI}$ risk perceptions were associated with the adoption of $\mathrm{HH}$.

Conclusion: Understanding the determinants of $\mathrm{HH}$ adoption is crucial for improving current practices and reducing $\mathrm{HAI}$ rates in hospital care. Our findings suggest that environmental strategies (e.g., additional sinks and $\mathrm{HH}$ stations) and organizational and communication strategies (e.g., continuing education and training sessions, support from hospital management, positive feedback) could help raise $\mathrm{HCWs}^{\prime}$ awareness of HAl prevention and adoption of HH guidelines.

KEYWORDS

Hand hygiene; infection control practice; healthcare provider; perception; belief; behaviours

\section{INTRODUCTION}

Healthcare-associated infections (HAI) continue to threaten patient safety in healthcare facilities. Approximately 80,000 to 90,000 patients suffer from a HAI in Quebec, Canada annually [1-3]. Clostridium difficile infections (CDI) and antibiotic-resistant infections such as methicillin-resistant Staphylococcus aureus and vancomycin-resistant enterococci are among the most common. These HAls significantly increase economic costs for healthcare systems as well as patient mortality and morbidity rates [4, 5].

Hand hygiene $(\mathrm{HH})$ is one of the most effective infection prevention and control (IPAC) practices for preventing HAI transmission [6-8]. The importance of adhering to $\mathrm{HH}$ guidelines has been studied extensively, yet compliance remains low among healthcare workers (HCWs) [7, 8]. A study by Kingston et al. (2017) surveyed nurses' HH attitudes and practices between 2007 and 2015 [9]. The authors found that self-reported alcoholbased hand rub (ABHR) was suboptimal, as fewer nurses reported compliance with ABHR in 2015 compared to 2007 (42\% and $55 \%$, respectively) [9]. The World Health Organization estimates that on average, HCWs wash their hands less than half the time they should [10].

Many quantitative research studies have examined the barriers to $\mathrm{HH}$ compliance, but few have resulted in the implementation of effective interventions [11-13]. Several qualitative studies have also been conducted on this topic. Smiddy et al. (2015) conducted a systematic review of 11 qualitative studies on HCWs' compliance with $\mathrm{HH}$ [14]. The authors' thematic analysis identified two broad categories of factors that influenced adherence to $\mathrm{HH}$ guidelines: motivational factors (i.e., social influences, acuity of patient care, self-protection, and use of cues) and perceptions of the work environment (i.e., resources, knowledge, information, and organizational culture). Chatfield et al. (2017) also reviewed 36 qualitative studies on $\mathrm{HH}$ among HCWs worldwide in a meta summary using the GRADE-

\footnotetext{
Acknowledgements: The authors would like to thank all participants and participating sites who accepted to take part in this study, offered valuable information, and who so kindly helped with participant recruitment. The authors would like to thank Dr. Michel Bergeron and his team for contributing to the advancement of our study by providing their valuable insights. 
CERQual process of quality assessment [15]. Findings from the study showed that although adequate $\mathrm{HH}$ training was available, content and reach could be improved. Furthermore, though management support evidenced through provision of human and hygiene resources was deemed necessary, it was often lacking. The authors also identified that $\mathrm{HCWs}^{\prime}$ subjective risk assessment also influenced $\mathrm{HH}$ behaviours.

Both reviews highlight the strengths of qualitative research. Understanding the factors that influence $\mathrm{HCWs}^{\prime}$ compliance with $\mathrm{HH}$ guidelines involves exploring their complex social behaviours within context-specific conditions [11]. Conditions that influence adherence to $\mathrm{HH}$ guidelines need to be assessed at a local level to inform the development of interventions that are appropriate to the setting, context, and subgroups of a given working environment [16]. Qualitative research can provide an in-depth understanding of HCWs' perceptions and practices within their local context and help fill existing knowledge gaps in a comprehensive way.

The purpose of this qualitative study was to explore HCWs' knowledge, attitudes, and practices toward $\mathrm{HH}[9,17]$. More specifically, our study examined the perceived barriers and enablers influencing $\mathrm{HH}$ adoption and explored $\mathrm{HCWs}^{\prime} \mathrm{HAI}$ risk perceptions. Previous qualitative studies on $\mathrm{HH}$ adherence have been conducted in Canada [7, 18-22]; however, most of these involved individual or group interviews or were conducted over five years ago. Furthermore, few have been conducted in the province of Quebec.

\section{METHODS}

This multicentre qualitative study employed an exploratory descriptive research design. Individual semi-structured interviews and observations were conducted over a period of two years, from May 2015 to May 2017, in nine hospitals in Quebec, Canada. The study was part of a larger research project with co-investigators from select hospital centres involved in the clinical development of a diagnostic test. The aims of the larger project were to develop, evaluate, and above all deliver to the healthcare system of Quebec novel rapid molecular diagnostic tests for the prevention, control, and treatment of CDIs and bacterial multidrug-resistant infections. One of the project's objectives was to evaluate the acceptability of the technology among end users and the usefulness of the results for real-time surveillance. Interviews on $\mathrm{HH}$ were conducted in this context [23].

\section{Participants}

Of the nine participating hospitals, four were in Montreal and five were in Quebec City. All were university-affiliated centres. Seven centres were francophone and two were anglophone. The number of admissions ranged from 12,948 to 36,730 per year. Bed capacity ranged from 256 to 1,053. HH observance rates, measured through regular audits [24, 25], were under 60\% for the year 2015-2016 for all participating centres. Informants were contacted by email and invited to participate in this study. The snowballing technique was used to identify other participants. The sampling was done purposively to include HCWs of varying levels of experience and with different professional backgrounds, including infection control professionals. All participants were employees at one of the nine participating sites. Participants included front-line nurses, nurse managers, physicians specializing in infectious diseases, infection prevention and control nurses (IPCN), and IPCN managers.

\section{Data collection}

This study was conducted on a voluntary basis. No incentives were given for participation. Individual in-person interviews were scheduled according to participants' availability and convenience and took place on-site in a private room. To conduct interviews and observations with front-line nurses, we first asked their clinical managers for their authorization. The interview guide included questions on $\mathrm{HH}$, IPAC, HAls, and risk perceptions and was tailored to participants' professions and adjusted throughout the data collection process as new themes emerged. Open-ended questions and dialogue were prioritized during interviews; however, conversations remained centred on the main topics and follow-up questions were asked when necessary. Interviews were conducted in either French or English by a senior researcher trained in social and cultural anthropology and a junior research assistant training in qualitative methods and public health. Interviews lasted approximately 30 to 45 minutes. All interviews were audio recorded and supplemented with field notes describing non-verbal responses, the interview context, and information given off the record. Participants were recruited until data saturation was achieved. During data collection, weekly team meetings were held to discuss preliminary findings and hypotheses and to review the interview guide.

To complement data collected during interviews, observations were conducted at each of the sites by both the senior researcher and junior research assistant. The observations consisted of following either a participating nurse, physician, or an IPCN for a period of four to eight hours. Observations were scheduled during weekdays according to participants' availability. HCWs' daily work routines were observed, including $\mathrm{HAI}$ and cohort management, nurse-patient interactions, sample collecting methods, environmental challenges, and workflow. Observations also took place at IPCN meetings and IPAC training sessions. The observations were conducted in order to provide a more contextual and detailed understanding of the participants' environments, workflow, and settings. Handwritten field notes were taken during observations, then transcribed. To avoid disrupting participants' work routines during observations, the research team interacted with participants only when certain situations or exchanges needed to be clarified.

All collected data was kept anonymous and was stored in a secure database to ensure participant confidentiality.

\section{Data analysis}

Data collection, interview transcriptions, and analysis occurred concurrently to monitor the progress of themes emerging from individual interviews. Using an inductive approach, transcripts and observational data were reviewed several times by members of the research team to identify emerging themes and subthemes [26]. Data was aggregated and coded thematically using NVivo 10 qualitative analysis software. A two-phased approach of ethnographic analysis was used: analysis and interpretation [27]. 
Data was coded using a constant-comparative and conceptdevelopment approach of emerging themes [26, 28]. Data analysis was performed for each individual hospital site to allow a better comparison between the different work environments. This involved data coding, in which the qualitative data was organized into patterns, categories, and basic descriptive units. Data interpretation was performed by the senior researcher in collaboration with the research team and involved attributing meaning and significance to the collected data by explaining patterns and identifying relationships among descriptive dimensions. Data obtained from all participants and sites were compared to generate and test interpretations of existing relationships between $\mathrm{HCWs}^{\prime}$ work environments, their risk perceptions of HAls, and their $\mathrm{HH}$ practices. The research team identified key verbatim quotations and observations that were most representative of the research findings and best illustrated the prevalence of the final themes and sub-themes. Quotations were edited for clarity and brevity and were labelled with participants' professions.

\section{Ethical considerations}

This study was approved by each site's research ethics board. Written informed consent was obtained from all study participants. Prior to data collection, participants were reminded that the contents of their interviews and observations would remain confidential and that no identifying information would be shared with their peers or senior management teams.

\section{RESULTS}

65 interviews and 18 observations were completed for this study. Participants' average years of work experience was 7.60 years (range: 0.6 to 30 years) with a median of five years. Participants' characteristics are provided in Table 1.

Data analysis revealed several factors that may influence $\mathrm{HCWs}^{\prime}$ adherence to $\mathrm{HH}$ recommendations in hospital care, with several shared perceptions across all sites. No significant differences were found between Montreal and Quebec City participants, nor between French- and English-speaking participants. Observations helped supplement findings from the individual interviews. No major discrepancies between participants' discourses (interviews) and practices (observations) were identified. Barriers as well as intervention and implementation strategies to enhance $\mathrm{HH}$ adoption are presented in Tables 2 and 3.

\section{Barriers}

HCWs' attitudes and perceptions of $\mathrm{HH}$

The importance of proper HH was acknowledged and accepted by all, though participants across all sites reported that $\mathrm{HH}$ was not consistently prioritized in practice. Nurses described physicians as non-compliant with $\mathrm{HH}$ recommendations. Conversely, IPCNs and other nurse participants claimed that $\mathrm{HH}$ resistance was not exclusive to physicians, as they described non-compliance to be present among hospital personnel, visitors, and patients. They also reported concerns regarding night teams and float nurses. These groups were harder to reach, which hindered IPAC communication, and were generally less compliant with guidelines and difficult to supervise. Similarly, IPAC nurses described being more vigilant with staff returning from vacation, as they tended to be less compliant with $\mathrm{HH}$.

At the individual level, lack of $\mathrm{HH}$ and IPAC knowledge and low $\mathrm{HAl}$ risk perceptions were identified as barriers to $\mathrm{HH}$ adoption. Interviewed IPAC nurses, nurse managers, and physicians reported that the invisibility of infectious agents did not favour $\mathrm{HH}$ among hospital staff, nor did it reinforce the legitimacy of certain IPAC practices. HCWs' lack of knowledge and awareness of HAl severity also discredited the importance of certain $\mathrm{HH}$ practices. Some nurses believed that gloves replaced proper handwashing. Others perceived patients to be at higher risk of contracting HAls than themselves. They also reported feeling confident in their abilities to properly apply IPAC measures, though very few expressed the need to protect their own health and safety during patient care.

\section{Contextual and organizational barriers}

Generally, each participating centre's infection control team reported implementing IPAC measures adapted to their own clinical setting, with a strong emphasis on $\mathrm{HH}$. $\mathrm{HH}$ was described as a key practice that HCWs needed to implement to successfully achieve an "IPAC culture" change within their hospital. Nurses and nurse managers reported that hospital management's support and commitment to IPAC helped reinforce the legitimacy of IPAC practices, including $\mathrm{HH}$.

However, $\mathrm{HH}$ performance was perceived as an additional task that hindered workflow for many HCWs. Contextual barriers to $\mathrm{HH}$ included heavy workloads and inadequate staffing. Nurses

TABLE 1: Sample characteristics $(N=65)$.

\begin{tabular}{|c|c|}
\hline Participant Characteristics & $\mathrm{N}(\%)$ \\
\hline \multicolumn{2}{|l|}{ Gender } \\
\hline Male & $13(20)$ \\
\hline Female & $52(80)$ \\
\hline \multicolumn{2}{|l|}{ Profession } \\
\hline Nurse $^{\mathrm{a}, \mathrm{b}}$ & $53(82)$ \\
\hline Physicians $^{\mathrm{c}}$ & $12(18)$ \\
\hline \multicolumn{2}{|l|}{ Role in hospital } \\
\hline Front-line care providers (nurses and physicians) & $28(43)$ \\
\hline Nurse managers & $13(20)$ \\
\hline Infection prevention and control staff and managers & $24(37)$ \\
\hline \multicolumn{2}{|l|}{ Experience (years) } \\
\hline 0 to 5 & $34(52)$ \\
\hline 6 to 10 & $17(26)$ \\
\hline 10 or more & $14(22)$ \\
\hline \multicolumn{2}{|l|}{ Language } \\
\hline French & $52(80)$ \\
\hline English & $13(20)$ \\
\hline \multicolumn{2}{|l|}{ City } \\
\hline Quebec City & $44(68)$ \\
\hline Montreal & $21(32)$ \\
\hline $\begin{array}{l}\text { Legend } \\
\text { alncludes nurse educators and nurse manager assistants. } \\
\text { bIncludes nurse managers and directors. } \\
\text { Includes only infection control specialists. }\end{array}$ & \\
\hline
\end{tabular}




\begin{tabular}{|c|c|}
\hline $\begin{array}{l}\text { HCWs' attitudes and } \\
\text { perceptions of } \mathrm{HH}\end{array}$ & Verbatim $1 /$ Observation \\
\hline $\begin{array}{l}\text { Differences across } \\
\text { health professions }\end{array}$ & $\begin{array}{l}\mathrm{NM}: \text { "[...] there are more doctors who have been observed compared to the rest of the team, so it } \\
\text { lowers our [hand hygiene audit] results, because they [doctors] don't do it all the time." }\end{array}$ \\
\hline $\begin{array}{l}\text { Lack of knowledge of and } \\
\text { education on } \mathrm{HH}\end{array}$ & $\begin{array}{l}\text { IN: "We discovered last year that some nurses, to go faster, were washing their gloves in between } \\
\text { patients instead of changing them. And they saw no problem with that." }\end{array}$ \\
\hline $\begin{array}{l}\text { Invisibility of pathogens } \\
\text { leading to lack of legitimacy } \\
\text { of some IPAC practices }\end{array}$ & $\begin{array}{l}\text { IN: "We can't see the bugs. It's an invisible contamination. It's like an imaginary problem [...]. } \\
\text { It [hand hygiene] is not integrated in the culture. It's not automatic." }\end{array}$ \\
\hline $\begin{array}{l}\text { Low risk perceptions: } \\
\text { wearing gloves }\end{array}$ & $\begin{array}{l}\text { NM: "Even if you have a pair of gloves on, you are not completely protected. There is always } \\
\text { something that will remain afterwards." }\end{array}$ \\
\hline $\begin{array}{l}\text { Self-protection not priori- } \\
\text { tized during patient care }\end{array}$ & $\begin{array}{l}\text { NM: "Employees need to understand that handwashing is to protect patients, but it's also to protect } \\
\text { themselves. You wash your hands to protect yourself." }\end{array}$ \\
\hline \multicolumn{2}{|c|}{ Contextual and organizational barriers } \\
\hline Heavy workload & $\begin{array}{l}\text { IM: "When you increase the workload of staff, you have non-compliance with everything really, } \\
\text { from environmental cleaning to handwashing." }\end{array}$ \\
\hline $\begin{array}{l}\text { Inadequate staffing and high } \\
\text { patient-nurse ratio }\end{array}$ & $\begin{array}{l}\text { IN: "[...] when we didn't have enough resources, like nurses working and caring for many patients at } \\
\text { the same time. Well hand hygiene showed lower audit results. Like it went down from } 70 \% \text { to } 50 \% . "\end{array}$ \\
\hline $\begin{array}{l}\text { Budgetary restrictions and } \\
\text { lack of time }\end{array}$ & $\begin{array}{l}\text { N: "Putting on your protective equipment, reserving your material, disinfecting all your tools when } \\
\text { you exit a patient's room. It all requires a lot of time. And time, well nurses don't have a lot of that." }\end{array}$ \\
\hline Supply issues & $\begin{array}{l}\mathrm{N}: \text { "[...] it's management, they're the ones who oversee the change. I think it's because the new } \\
\text { gloves cost less. So, we're not the ones to decide [...] like gloves, care material and gloves, they } \\
\text { never ask us our opinion, it just happens." }\end{array}$ \\
\hline \multicolumn{2}{|l|}{ Environmental barriers } \\
\hline $\begin{array}{l}\text { Limited space on hospital } \\
\text { floors }\end{array}$ & $\begin{array}{l}\text { OB: There is insufficient space on the floor to install more sinks. HCWs do not have close access to } \\
\text { sinks to wash their hands. }\end{array}$ \\
\hline $\begin{array}{l}\text { Lack of sinks and/or bad } \\
\text { positioning of sinks on hos- } \\
\text { pital units }\end{array}$ & $\begin{array}{l}\text { MD: "[...] we absolutely have to wash hands with water and use soap like in the good old days. Hos- } \\
\text { pitals are not equipped with sinks. So often, the sink is } 15 \text { to } 20 \text { feet away. The health provider has to } \\
\text { go all the way there, wash their hands, come back, so there is a big loss of time and it's not efficient." }\end{array}$ \\
\hline \multicolumn{2}{|l|}{ Communication barriers } \\
\hline $\begin{array}{l}\text { Hierarchical working } \\
\text { relationships and } \\
\text { HCW resistance }\end{array}$ & $\begin{array}{l}\text { IM: "One of the problems we've had, is that yes, we'll be quick to criticize a porter or a nurse who } \\
\text { didn't wash their hands. But when it's a doctor or something, well we won't say anything because } \\
\text { we don't want them to answer us rudely." }\end{array}$ \\
\hline $\begin{array}{l}\text { Youth, maturity, and } \\
\text { relational proximity }\end{array}$ & $\begin{array}{l}\text { NM: "[...] our teams are young and all around the same age }[\ldots] \text { when I need to say something to } \\
\text { someone about hand hygiene, I'll do it within the hour if I see them and it'll be professional. But } \\
\text { what taints everything is that they talk amongst themselves. They're family, they're friends." }\end{array}$ \\
\hline $\begin{array}{l}\text { Negative perceptions of } \\
\text { infection control team }\end{array}$ & $\begin{array}{l}\text { OB: Some nurses ignored the IPAC nurse when she reminded them to wash their hands. They } \\
\text { pretended that she wasn't there and did not answer her when she spoke to them. }\end{array}$ \\
\hline
\end{tabular}

reported frequently working overtime to compensate for the shortage of staff, which in turn may compromise the quality of care and lead to professional burnout.

\section{Environmental barriers}

Environmental barriers included features of hospitals' physical layout and structure that challenged or restricted participants' $\mathrm{HH}$ performance. Frequently reported barriers included limited space, the absence of single-patient rooms, and the lack of sinks and $\mathrm{HH}$ stations. Furthermore, the lack of single-patient rooms was reported to be problematic, as restricted space on care units and inadequate isolation facilities compromised the application of IPAC measures. However, sites equipped with numerous single-patient rooms reported having frequent $\mathrm{HAI}$ outbreaks, which could be explained by staff's poor compliance with $\mathrm{HH}$ in between patients.

\section{Communication barriers}

Communication posed a major challenge for IPAC teams. The increased number of HCWs in hospitals and high employee turnover rates made the dissemination of IPAC and $\mathrm{HH}$ recommendations more challenging. Other communication barriers included hierarchical working relationships (i.e., between physicians and nurses), which impeded communication relating to IPAC; silo mentality, where IPAC information was segregated among HCWs belonging to the same care unit or profession; and concerns about critical feedback, where HCWs who had developed friendships with some of their peers were uncomfortable reminding colleagues to comply with $\mathrm{HH}$ guidelines. Communication and adherence to IPAC measures were also hindered by HCWs' negative perceptions of IPAC teams, as some perceived them to be the "police." 


\begin{tabular}{|c|c|}
\hline Organizational strategies & Verbatim¹/Observation \\
\hline $\begin{array}{l}\text { Dissemination of IPAC } \\
\text { and } \mathrm{HH} \text { guidelines using } \\
\text { existing roles }\end{array}$ & $\begin{array}{l}\mathrm{N}: \text { "The infection control team will address the nurses directly, but }[\ldots]] \text { I, myself, or the nurse } \\
\text { managers will act as sort of the intermediary to spread the word to all the staff." }\end{array}$ \\
\hline $\begin{array}{l}\text { Implementation of a new } \\
\text { role: infection control agents, } \\
\text { with the goal of promoting } \\
\text { IPAC and HH guidelines }\end{array}$ & $\begin{array}{l}\text { IM: "We have infection control agents on each unit. They have a day of infection control and } \\
\text { prevention training [...] those working on units refer to those agents. It's infection prevention } \\
\text { promotion, it's our transmission belt for communicating." }\end{array}$ \\
\hline $\begin{array}{l}\text { Implementing } \mathrm{HH} \text { games on } \\
\text { hospital units }\end{array}$ & MD: "That [certification program] will help develop infection control and prevention culture." \\
\hline \multicolumn{2}{|l|}{ Communication strategies } \\
\hline $\begin{array}{l}\text { Implementing positive } \\
\text { deviance (feedback, positive } \\
\text { leaders) }\end{array}$ & $\begin{array}{l}\text { IM: "Positive deviance is a lot of things [...] when you see someone doing something well, } \\
\text { it's important to point them out to their peers because others will want that positive } \\
\text { reinforcement as well." }\end{array}$ \\
\hline \multirow{2}{*}{$\begin{array}{l}\text { Posting posters, handouts, } \\
\text { reminders }\end{array}$} & $\begin{array}{l}\text { IN: "Campaigning, we have posters. Each unit has them to motivate their team and remind the } \\
\text { staff to wash their hands." }\end{array}$ \\
\hline & $\begin{array}{l}\text { OB: Posters are placed in strategic locations to be visible to all. Locations included elevators, } \\
\text { cafeteria, walls of care units, IPAC offices, and even bathrooms. }\end{array}$ \\
\hline \multirow{2}{*}{$\begin{array}{l}\text { Audits and publicizing } \\
\mathrm{HH} \text { audit results }\end{array}$} & $\begin{array}{l}\text { IM: "So now our hand hygiene compliance results will become public }[\ldots] \text { so everybody is going to } \\
\text { be accountable." }\end{array}$ \\
\hline & $\begin{array}{l}\text { OB: Hand hygiene audit results are clearly displayed at entrance of care unit. They are visible to } \\
\text { visitors, patients, and cleaning staff. }\end{array}$ \\
\hline $\begin{array}{l}\text { Implementing online train- } \\
\text { ing sessions and e-learning }\end{array}$ & $\begin{array}{l}\text { IM: "There are also videos, e-learning videos is what we call them, online sessions where they can } \\
\text { learn [...] for instance on hand hygiene." }\end{array}$ \\
\hline $\begin{array}{l}\text { Support from hospital man- } \\
\text { agement to increase nurses' } \\
\text { adherence to IPAC practices }\end{array}$ & $\begin{array}{l}\text { IM: "Implementing these measures has significantly decreased the pressure put on the infection } \\
\text { control team. It's supported by management so there's nothing better than that." }\end{array}$ \\
\hline $\begin{array}{l}\text { Positive working relationship } \\
\text { with infection control team }\end{array}$ & $\begin{array}{l}\text { N: "It's not long before the infection control team is advised. They are always advised as soon as } \\
\text { something happens." }\end{array}$ \\
\hline \multicolumn{2}{|l|}{ Environmental strategies } \\
\hline $\begin{array}{l}\text { Increased access to single- } \\
\text { patient rooms }\end{array}$ & $\begin{array}{l}\text { IN: "[...] it's a government recommendation that all new rooms created in the healthcare system be } \\
\text { private to prevent infection transmission." }\end{array}$ \\
\hline \multirow{2}{*}{$\begin{array}{l}\text { Installation of additional } \\
\text { sinks, soap dispensers, and } \\
\text { HH stations }\end{array}$} & $\begin{array}{l}\mathrm{N} \text { : "We replaced the hand sanitizers so that they were more accessible, more visually present, to } \\
\text { remind the staff that: 'OK, you need to wash your hands'." }\end{array}$ \\
\hline & $\begin{array}{l}\text { OB: Extra sinks are installed outside patient rooms. Visible "Stop" signs are placed near soap } \\
\text { dispensers to remind visitors and staff to wash their hands. }\end{array}$ \\
\hline
\end{tabular}

\section{Intervention and implementation strategies to enhance $\mathrm{HH}$ adherence}

Findings from this study have shown that IPAC teams have implemented different strategies to efficiently disseminate IPAC information in hospitals and change HCWs' practices. As shown in Figure 1, the interventions and strategies that have been implemented in participating hospital centres were in direct response to the barriers that have been identified.

\section{Organizational strategies}

At the organizational level, IPAC teams benefited from the support of nurse managers, assistant nurse managers, or nurse educators to facilitate the implementation of $\mathrm{HH}$ guidelines. In some participating centres, nurses who wished to promote IPAC practices on their respective units could volunteer to receive additional training to become "IPAC agents." Finally, interviewed IPAC nurses and physicians reported that support from hospital management was crucial to promote staff's adherence to $\mathrm{HH}$ and reinforce the legitimacy of IPAC.

Nevertheless, HCWs' negative perceptions of infection control teams in some hospitals could have negatively impacted these efforts. Some nurses described IPAC nurses as the bearers of bad news and criticism, whereas some IPAC nurse participants reported feeling unwelcome and misunderstood by hospital personnel. HCWs' acceptance of IPCNs is important, as it may strengthen their commitment to IPAC.

\section{Communication strategies}

Communication strategies included distributing handouts and reminders year-round, especially during the week of the Canadian Patient Safety Institute's National Hand Hygiene Day in May. Other strategies included publicizing $\mathrm{HH}$ audit results in care units, implementing online IPAC training sessions (e-learning), having frequent information sessions for hospital 


\section{FIGURE 1: Barriers and strategies to enhance $\mathrm{HH}$ adherence.}

\section{Context \& organization}

\section{Barriers:}

- Heavy workload

- Inadequate staffing

\section{Strategies:}

- Managerial support

- Hospital management support

- Training IPC agents
Environment

\section{Barriers:}

- Limited space

- Lack of single patient rooms

- Lack of sinks and HH stations

Strategies:

- Additional sinks \& HH stations

- More single-patient rooms

- Floor space reorganization

\section{Communication}

\section{Barriers:}

- Increased number of HCWs

- Employee turnover rates

- Hierarchical working relationship

- Silo mentality

- Concerns about critical feedback

- Negative perceptions of IPC teams

\section{Strategies:}

- Handouts \& reminders

- HH audit reports publication

- Training sessions

- Frequent \& short meetings

- Positive feedback

- Use of UV light personnel, and handwashing under ultraviolet lights ${ }^{1}$ to reveal bacteria and enhance $\mathrm{HAl}$ awareness. One strategy relied on HCWs to act as role models and "IPAC educators" by disseminating IPAC information, increasing $\mathrm{HAI}$ awareness, and promoting the adoption of IPAC measures. Lastly, some respondents mentioned using a "positive deviance" approach [6, 18], where positive feedback was given to those who adhered to $\mathrm{HH}$ guidelines, viewing them as "positive leaders," as opposed to giving critical feedback to non-compliant HCWs. However, issues in providing critical feedback to non-compliant colleagues were also reported by participants.

\section{Environmental strategies}

Finally, in newer hospitals, environmental strategies included the installation of additional sinks and $\mathrm{HH}$ stations and an increased number of single-patient rooms. In older hospital centres, participants described reorganizing floor space and modifying certain IPAC measures to better fit their actual clinical environment and maximize space.

\section{DISCUSSION}

Though $\mathrm{HH}$ is a priori a simple task to perform and incorporate into clinical practice, adherence to $\mathrm{HH}$ guidelines among HCWs remains low. Some qualitative studies have explored HCWs' perceptions of $\mathrm{HH}$ and HAls in Quebec hospital care [29], though few have been multicentre studies [30, 31]. Previous quantitative studies conducted in Quebec have shown that $\mathrm{HCW}$ adherence to IPAC practices is sub-optimal but have often failed to identify reasons why [32-34].

Though most nurses recognized the importance of proper $\mathrm{HH}$ in preventing $\mathrm{HAl}$ transmission [16, 19, 35], patients' needs and fast-paced environments made it difficult for nurses to strictly adhere to $\mathrm{HH}$ guidelines and prioritize them in practice. Previous research has noted the importance of organizational-level support and leadership to facilitate the implementation of $\mathrm{HAI}$ prevention initiatives and encourage an IPAC cultural change within health establishments. Furthermore, adequate nurse staffing levels have been associated with lower rates of patient mortality and morbidity and lower rates of HAls [36, 37]. Similar to previous studies, environmental barriers consisted of poor physical structure and lack of resources, such as poor placement or absence of sinks and handwashing stations [18, 36, 38, 39]. While singlepatient rooms may facilitate patient management [40], our findings and other studies indicate that on their own they are unable to reduce $\mathrm{HAI}$ transmission [41-43].

In this study as in others, HCWs' "lack of knowledge and education" of $\mathrm{HH}$ guidelines was reported to be a significant barrier at the individual level $[35,36]$. As HCWs' poor levels of hospital hygiene knowledge were a reoccurring theme across sites, this could indicate that current educational initiatives are not conducive to learning. IPAC training tailored to HCWs' respective professions may help address this issue. However, according to one study, low $\mathrm{HH}$ compliance is not necessarily linked to HAI knowledge, but rather to HCWs not incorporating this knowledge into their daily practice, which could be due to low motivation and $\mathrm{HAl}$ awareness, heavy workloads, and facilities' physical structures [38]. Though IPAC education remains an important component of improving $\mathrm{HH}$ adherence, training aimed at improving $\mathrm{HCWs}^{\prime}$ preventive beliefs and $\mathrm{HAI}$ risk perceptions should also be considered [8].

Nurses interviewed in this study claimed that physicians did not comply with $\mathrm{HH}$ recommendations, which has been cited in previous research [14, 15]. However, our findings indicate that low adherence to $\mathrm{HH}^{\mathrm{H}}$ was not solely a physicians' problem, as it was reported to also be present among various

${ }^{1}$ The ultraviolet light is used to test HCWs' handwashing technique and enhance their awareness of infection transmission. Though bacteria are invisible to the naked eye, the "glow" of the ultraviolet light reveals any bacteria left on the hands following handwashing. 
groups of HCWs and visitors. As described by Shah et al. (2015), encouraging adherence to IPAC practices can be challenging in multidisciplinary teams where perceptions of clinical practice may vary and where HCWs are more likely to adhere to the norms of their respective professions [16].

In this context, IPAC teams relied on different strategies to enhance HCWs' adherence to $\mathrm{HH}$. Our findings have highlighted that organizational climate or "pro-IPAC culture," $\mathrm{HCW} s^{\prime}$ commitment to IPAC through different communication strategies, IPAC leadership initiatives, as well as knowledge and self-efficacy appeared to be highly influential success factors. Our findings also showed that barriers to $\mathrm{HH}$ adherence were complex and context-specific, and successful IPAC interventions were tailored to $\mathrm{HCWs}^{\prime}$ context.

Though there is no "one size fits all" IPAC strategy, findings from our study suggest that continuous education, HCW cohesion and communication, organizational IPAC support, accessibility of materials, and improving facilities' physical layouts may help improve $\mathrm{HH}$ compliance in hospital care. Prioritizing HCW communication at all levels may improve cohesion and promote a workplace where feedback is welcomed and encouraged, which has previously been linked to higher $\mathrm{HH}$ compliance rates [11]. A systematic review of $\mathrm{HH}$ clinical trials conducted by Kingston et al. (2016) also concluded that multimodal approaches to $\mathrm{HH}$ intervention strategies can improve $\mathrm{HH}$ adherence among HCWs [6].

Our study had some limitations. Participation was voluntary and HCWs who were unavailable or declined to participate may therefore have characteristics and opinions that differ from those recruited. Furthermore, there was an under-representation of men and front-line nurses in our final sample. Recruiting frontline nurses was challenging, as they often had heavy workloads and needed the authorization of their clinical managers in order to participate in our study. Though data saturation was achieved, our findings could not adequately represent the views of all front-line nurses. Moreover, participants may have enhanced their responses to interview questions to provide socially desirable answers. We tried to control this by conducting observations and interviews with multiple participants from the same health facility, which allowed us to observe HCWs' behaviours and helped us identify any missing information from participant interviews. In addition, we used different methodological techniques that were intended to enrich validity: purposeful sampling using diversification criteria, grounded theory, and double coding [28]. Finally, only primary results have been developed in this manuscript to respect the journal's guidelines regarding article length.

To conclude, understanding the determinants of $\mathrm{HH}$ adoption is crucial in developing and implementing sustainable $\mathrm{HH}$ guidelines in hospitals. Strategies that consider HCWs' local contexts and opinions may increase IPAC awareness, improve cohesion among professions, and promote a safer working environment. Our findings provide valuable insight into the factors that may influence $\mathrm{HCWs}^{\prime}$ compliance with $\mathrm{HH}$ in Quebec hospital care. We have identified key barriers at the organizational, environmental, and individual levels, which include inadequate staffing, demanding workloads, lack of sinks and $\mathrm{HH}$ stations, lack of knowledge, and reduced $\mathrm{HAI}$ risk perceptions. Our findings also indicate that communication strategies are often prioritized in hospitals to overcome these barriers. Further research is needed to verify whether the representations identified in this study are present among all HCWs working within Quebec hospital centres and elsewhere in Canada.

\section{REFERENCES}

1. Fakih, I., Fortin, É., Smith, M. A., Carignan, A., Tremblay, C., Villeneuve, J., Moisan, D., Frenette, C., \& Quach, C. (2018). A ten-year review of healthcare-associated bloodstream infections from forty hospitals in Québec, Canada. Infection Control \& Hospital Epidemiology, 39(10), 1202-1209. doi: 10.1017/ice.2018.185

2. Gilca, R., Hubert, B., Fortin, E., Gaulin, C., \& Dionne, M. (2010). Epidemiological patterns and hospital characteristics associated with increased incidence of Clostridium difficile infection in Quebec, Canada, 19982006. Infection Control \& Hospital Epidemiology, 31(9), 939-947. doi: https://doi.org/10.1086/655463

3. Gravel, D., Taylor, G., Ofner, M., Johnston, L., Loeb, M., Roth, V. R., Stegenga, J., \& Bryce, E. (2007). Point prevalence survey for healthcareassociated infections within Canadian adult acute-care hospitals. Journal of Hospital Infection, 66(3), 243-248. doi: 10.1016/j.jhin.2007.04.008

4. Yokoe, D. S., Anderson, D. J., Berenholtz, S. M., Calfee, D. P., Dubberke, E. R., Ellingson, K. D., Gerding, D. N., Haas, J. P., Kaye, K. S., Klompas, M., Lo, E., Marschall, J., Mermel, L. A., Nicolle, L. E., Salgado, C. D., Bryant, K., Classen, D., Crist, K., Deloney, V. M., Fishman, N. O., Foster, N., Goldmann, D. A., Humphreys, E., Jernigan, J. A., Padberg, J., Perl, T. M., Podgorny, K., Septimus, E. J., VanAmringe, M., Weaver, T., Weinstein, R. A., Wise, R., \& Maragakis, L. L. (2014). A compendium of strategies to prevent healthcare-associated infections in acute care hospitals: 2014 updates. American Journal of Infection Control, 42(8), 820-828. doi: 10.1016/j.ajic.2014.07.002

5. Mittmann, N., Koo, M., Daneman, N., McDonald, A., Baker, M., Matlow, A., Krahn, M., Shojania, K. G., \& Etchells, E. (2012). The economic burden of patient safety targets in acute care: A systematic review. Drug, Healthcare and Patient Safety, 4, 141. doi: 10.2147/DHPS.S33288

6. Kingston, L., O'Connell, N. H., \& Dunne, C. P. (2016). Hand hygienerelated clinical trials reported since 2010: A systematic review. Journal of Hospital Infection, 92(4), 309-320. doi: 10.1016/j.jhin.2015.11.012

7. Kirk, J., Kendall, A., Marx, J. F., Pincock, T., Young, E., Hughes, J. M., \& Landers, T. (2016). Point of care hand hygiene-where's the rub? A survey of US and Canadian health care workers' knowledge, attitudes, and practices. American Journal of Infection Control, 44(10), 1095-1101. doi: 10.1016/j.ajic.2016.03.005

8. Ciofi degli Atti, M. L., Tozzi, A. E., Ciliento, G., Pomponi, M., Rinaldi, S., \& Raponi, M. (2011). Healthcare workers' and parents' perceptions of measures for improving adherence to hand-hygiene. BMC Public Health, 11, 466. doi: 10.1186/1471-2458-11-466

9. Kingston, L. M., Slevin, B. L., O'Connell, N. H., \& Dunne, C. P. (2017). Hand hygiene: Attitudes and practices of nurses, a comparison between 2007 and 2015. American Journal of Infection Control, 45(12), 13001307. doi: 10.1016/j.ajic.2017.08.040

10. World Health Organization. (2009). WHO guidelines on hand hygiene in health care. Retrieved from http://www.who.int/gpsc/5may/ tools/9789241597906/en/

11. Erasmus, V., Daha, T. J., Brug, H., Richardus, J. H., Behrendt, M. D., Vos, M. C., \& van Beeck, E. F. (2010). Systematic review of studies on compliance with hand hygiene guidelines in hospital care. Infection Control \& Hospital Epidemiology, 31(3), 283-294. doi: 10.1086/650451

12. Gould, D. J., Moralejo, D., Drey, N. \& Chudleigh, J. H. (2010). Interventions to improve hand hygiene compliance in patient care. Cochrane Database of Systematic Reviews, 9, CD005186. doi: 10.1002/14651858. CD005186.pub3 
13. Huis, A., van Achterberg, T., de Bruin, M., Grol, R., Schoonhoven, L., \& Hulscher, M. (2012). A systematic review of hand hygiene improvement strategies: A behavioural approach. Implementation Science, 7, 92. doi: 10.1186/1748-5908-7-92

14. Smiddy, M. P., O' Connell, R., \& Creedon, S. A. (2015). Systematic qualitative literature review of health care workers' compliance with hand hygiene guidelines. American Journal of Infection Control, 43(3), 269-274. doi: 10.1016/j.ajic.2014.11.007

15. Chatfield, S. L., DeBois, K., Nolan, R., Crawford, H., \& Hallam, J. S. (2017). Hand hygiene among healthcare workers: A qualitative meta summary using the GRADE-CERQual process. Journal of Infection Prevention, 18(3), 104-120. doi: 10.1177/1757177416680443

16. Shah, N., Castro-Sánchez, E., Charani, E., Drumright, L. N., \& Holmes, A. H. (2015). Towards changing healthcare workers' behaviour: A qualitative study exploring non-compliance through appraisals of infection prevention and control practices. Journal of Hospital Infection, 90(2), 126-134. doi: 10.1016/j.jhin.2015.01.023

17. Dixit, D., Hagtvedt, R., Reay, T., Ballermann, M., \& Forgie, S. (2012). Attitudes and beliefs about hand hygiene among paediatric residents: A qualitative study. BMJ Open, 2(6), e002188. doi: 10.1136/bmjopen-2012-002188

18. Squires, J. E., Linklater, S., Grimshaw, J. M., Graham, I. D., Sullivan, K., Bruce, N., Gartke, K., Karovitch, A., Roth, V., Stockton, K., Trickett, J., Worthington, J., \& Suh, K. N. (2014). Understanding practice: Factors that influence physician hand hygiene compliance. Infection Control and Hospital Epidemiology, 35(12), 1511-1520. doi: https:// doi.org/10.1086/678597

19. Jang, J. H., Wu, S., Kirzner, D., Moore, C., Youssef, G., Tong, A., Lourenco, J., Stewart, R. B., McCreight, L. J., Green, K., \& McGeer, A. (2010). Focus group study of hand hygiene practice among healthcare workers in a teaching hospital in Toronto, Canada. Infection Control \& Hospital Epidemiology, 31(2), 144-150. doi: $10.1086 / 649792$

20. Boscart, V. M., Fernie, G. R., Lee, J. H., \& Jaglal, S. B. (2012). Using psychological theory to inform methods to optimize the implementation of a hand hygiene intervention. Implementation Science, 7, 77. doi: https://doi.org/10.1186/1748-5908-7-77

21. Bryce, E., Islam, S., Nelson, B., Gamage, B., Wilson, R., Welsh, P., \& Han, G. (2014). Impact of a mandated provincial hand hygiene program: Messages from the field. American Journal of Infection Control, 42(7), 708-712. doi: https://doi.org/10.1016/j.ajic.2014.04.004

22. Zimmerman, B., Reason, P., Rykert, L., Gitterman, L., Christian, J., \& Gardam, M. (2013). Front-line ownership: Generating a cure mindset for patient safety. Healthcare Papers, 13(1), 6-22. Retrieved from https://www.ncbi.nlm.nih.gov/pubmed/23803349

23. Bissonnette, L., Chapdelaine, S., Peytavi, R., Huletsky, A., Stewart, G., Boissinot, M., Allibert, P., \& Bergeron, M. B. (2014). A revolutionary microfluidic stand-alone platform (GenePOC) for nucleic-acid based point-of-care diagnostics. In G. J. Kost \& C. M. Curtis (Eds.), Global point of care: Strategies for disasters, emergencies, and public health resilience (235-247). Washington, D.C.: AACC Press.

24. Ministère de la Santé et des Services sociaux du Québec. (2017). Taux de conformité aux pratiques exemplaires d'hygiène des mains dans les établissements. Retrieved from http://www.msss.gouv.qc.ca/ repertoires/indicateurs-gestion/indicateur-000166/?\&date $=$ DESC

25. Ministère de la Santé et des Services sociaux du Québec. (2015). Plan d'action ministériel 2015-2020 sur la prévention et le contrôle des infections nosocomiales: Pour une prestation sécuritaire des soins de santé au Québec. Retrieved from http://publications.msss.gouv. qc.ca/msss/fichiers/2015/15-209-01W.pdf

26. Richards, L. (2010). Handling qualitative data: A practical guide (2nd ed.). London: Sage Publications.

27. Fetterman, D. M. (2010). Ethnography: Step-by-step (3rd ed.). Thousand Oaks, CA: Sage Publications.

28. Strauss, A. \& Corbin, J. (1998). Basics of qualitative research: Techniques and procedures for developing grounded theory (2nd ed.). Thousand Oaks, CA: Sage Publications.
29. Létourneau, J., Alderson, M., \& Leibing, A. (2017). Positive deviance and hand hygiene of nurses in a Quebec hospital: What can we learn from the best? American Journal of Infection Control, 46(5), 558-563. doi: 10.1016/j.ajic.2017.10.005

30. Seifert, A. M., \& O'Neill, M. (2013). Comprendre les représentations du personnel soignant face aux infections nosocomiales au Clostridium difficile au Québec pour mieux en promouvoir la santé. Global Health Promotion, 20(3), 58-65. doi: https://doi.org/10.1177/1757975913496123

31. Martel, J., Bui-Xuan, E.-F., Carreau, A.-M., Carrier, J.-D., Larkin, É., Vlachos-Mayer, H., \& Dumas, M.-E. (2013). Respiratory hygiene in emergency departments: Compliance, beliefs, and perceptions. American Journal of Infection Control, 41(1), 14-18. doi: https://doi.org/10.1016/j. ajic.2011.12.019

32. Bilodeau, H., \& Robert-Huot, G. (2012). Connaissances, pratiques et perceptions en matière de prévention et de contrôle des infections acquises en milieu hospitalier chez le personnel d'entretien et préposés aux bénéficiaires. Retrieved from https://sac.uqam.ca/upload/files/ Bilodeau_2012.pdf

33. Gonzales, M., Rocher, I., Fortin, É., Fontela, P., Kaouache, M., Tremblay, C., Frenette, C., \& Quach, C. (2013). A survey of preventive measures used and their impact on central line-associated bloodstream infections (CLABSI) in intensive care units (SPIN-BACC). BMC Infectious Diseases, 13, 562. doi: 10.1186/1471-2334-13-562

34. Garenc, C., \& Frenette, C. (2015). Étude sur les mesures appliquées dans les installations de soins de courte durée du Québec au regard de la prévention et du contrôle de la diarrhée associée au Clostridium difficile. Retrieved from https://www.inspq.qc.ca/publications/2013

35. Efstathiou, G., Papastavrou, E., Raftopoulos, V., \& Merkouris, A. (2011). Factors influencing nurses' compliance with standard precautions in order to avoid occupational exposure to microorganisms: A focus group study. BMC Nursing, 10(1). doi: https://doi.org/10.1186/1472-6955-10-1

36. Seibert, D. J., Speroni, K. G., Oh, K. M., Devoe, M. C., \& Jacobsen, K. H. (2014). Preventing transmission of MRSA: A qualitative study of health care workers' attitudes and suggestions. American Journal of Infection Control, 42(4), 405-411. doi: 10.1016/j.ajic.2013.10.008

37. Cimiotti, J. P., Aiken, L. H., Sloane, D. M., \& Wu, E. S. (2012). Nurse staffing, burnout, and health care-associated infection. American Journal of Infection Control, 40(6), 486-490. doi: 10.1016/j.ajic.2012.02.029

38. Oliveira, A. C., Cardoso, C. S., \& Mascarenhas, D. (2010). [Contact precautions in intensive care units: Facilitating and inhibiting factors for professionals' adherence]. Revista Da Escola De Enfermagem Da U S P, 44(1), 161-165. Retrieved from https:/www.ncbi.nlm.nih.gov/ pubmed/20394234

39. Løyland, B., Wilmont, S., Hessels, A. J., \& Larson, E. (2016). Staff knowledge, awareness, perceptions, and beliefs about infection prevention in pediatric long-term care facilities. Nursing Research, 65(2), 132-141. doi: 10.1097/NNR.0000000000000136

40. Stiller, A., Salm, F., Bischoff, P., \& Gastmeier, P. (2016). Relationship between hospital ward design and healthcare-associated infection rates: A systematic review and meta-analysis. Antimicrobial Resistance \& Infection Control, 5(1), 51. doi: https://doi.org/10.1186/s13756-016-0152-1

41. Ellison, J., Southern, D., Holton, D., Henderson, E., Wallace, J., Faris, P., Ghali, W. A., \& Conly, J. (2014). Hospital ward design and prevention of hospital-acquired infections: A prospective clinical trial. Canadian Journal of Infectious Diseases and Medical Microbiology, 25(5), 265-270. Retrieved from https://www.ncbi.nlm.nih.gov/pmc/articles/ PMC4211350/

42. Landelle, C., Pagani, L., \& Harbarth, S. (2013). Is patient isolation the single most important measure to prevent the spread of multidrug-resistant pathogens? Virulence, 4(2), 163-171. doi: 10.4161/viru.22641

43. Voigt, J., Mosier, M., \& Darouiche, R. (2018). Private rooms in low acuity settings: A systematic review of the literature. Health Environments Research \& Design Journal, 11(1), 57-74. doi: $10.1177 / 1937586717702597$ 